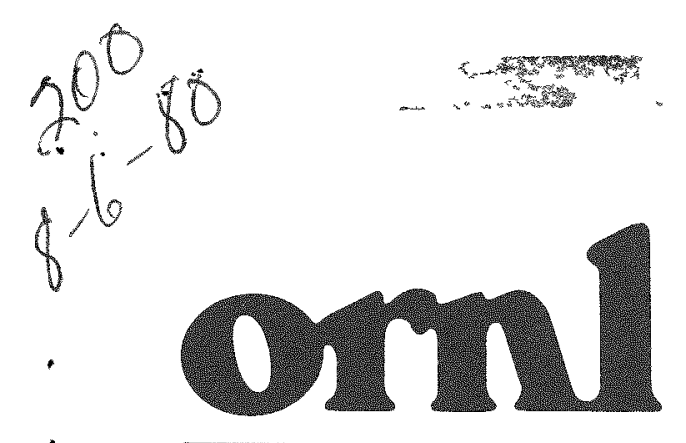

OAK RIDGE NATIONAL LABORATORY

\section{UNION \\ CARBIDE}

Arillow

ORNL/TM-7393

\title{
The Interaction of Silver and Palladium with Sillicon Carbide in HTGR Fuel Particles- Preliminary Report
}

\author{
R. J. Lauf
}

OPEATED BY

UNION GARBDE CORPOBATIOK FDP THE UIITED STATES DEPARTMENT OF EIEIOY 
Primted in the United States of America Avaliable from National Technical information Service

U.S. Deparment of Commerce

5285 Pon Royal Road, Springfield, Virgma 22161

NTIS price codes-Prnted Copy: A03 Microfiche A0I

Thus report was prepared as an account of work sponsored by an agency of the Unted States Government Nelher the Unthed States Govemment not any agency thereof, nor any of therr employees, makes any warranty, express or impled, or assumes any legal labilly or responsiblity for the accuracy, completeness, or usefulness of any information, apparatus, product, or process disclosed, or represents that ts use would not intringe privately owned rights Reterence heren to any spectic commercial product, process, or semce by trade name, trademark, manufacturer, of otherwise, does not necessanly constute or imply its endorsement, recommendation, or favorng by the Unted States Govemment or any agency thereof The views and opmions of authors expressed heren do not necessarly state or reflect those of the Unted States Govenmen or any agency thereof 


\section{DISCLAIMER}

This report was prepared as an account of work sponsored by an agency of the United States Government. Neither the United States Government nor any agency Thereof, nor any of their employees, makes any warranty, express or implied, or assumes any legal liability or responsibility for the accuracy, completeness, or usefulness of any information, apparatus, product, or process disclosed, or represents that its use would not infringe privately owned rights. Reference herein to any specific commercial product, process, or service by trade name, trademark, manufacturer, or otherwise does not necessarily constitute or imply its endorsement, recommendation, or favoring by the United States Government or any agency thereof. The views and opinions of authors expressed herein do not necessarily state or reflect those of the United States Government or any agency thereof. 


\section{DISCLAIMER}

Portions of this document may be illegible in electronic image products. Images are produced from the best available original document. 
ORNL/TM-7393

Distribution

Category UC-77

Contract No. W-7405-eng-26

METALS AND CERAMICS DIVISION

HTGR BASE TECHNOLOGY PROGRAM

Fueled Graphite Development (189a 01330)

THE INTERACTION OF SILVER AND PALLADIUM WITH SILICON CARBIDE IN HTGR FUEL PARTICLES - PRELIMINARY REPORT

R. J. Lauf

Date Published: July 1980

NOTICE: This document contains information of a preliminary nature. It is subject to revision or correction and therefore does not represent a final report.

\author{
OAK RIDGE NATIONAL LABORATORY \\ Oak Ridge, Tennessee 37830 \\ operated by \\ UNION CARBIDE CORPORATION \\ for the \\ DEPARTMENT OF ENERGY
}




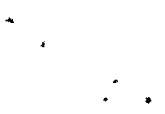

' 


\section{CONTENTS}

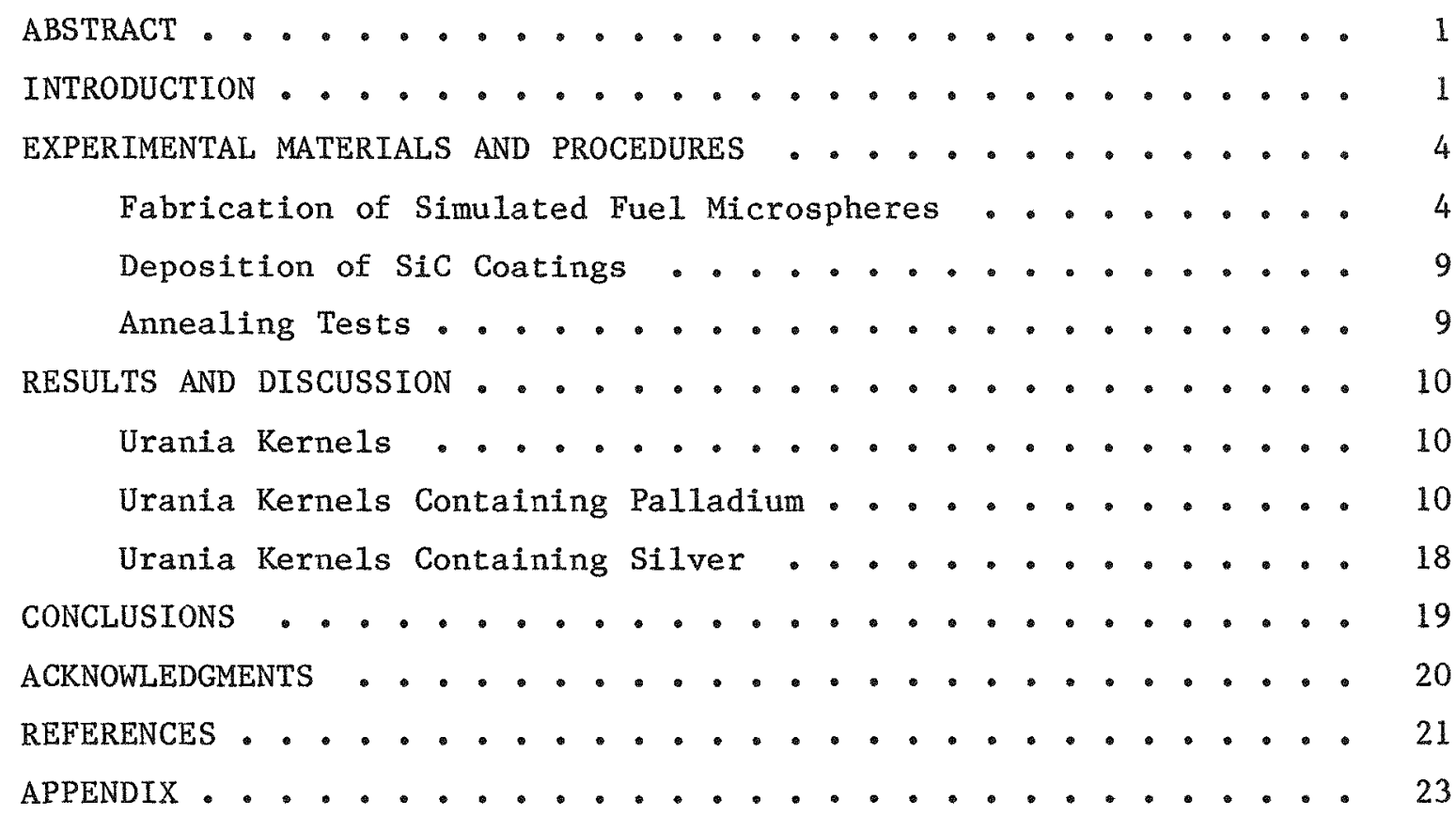


THE INTERACTION OF SILVER AND PALLADIUM WITH SILICON CARBIDE

IN HTGR FUEL PARTICLES - PRELIMINARY REPORT

R. J. Lauf

ABSTRACT

Fuel particles for the High-Temperature Gas-Cooled Reactor contained a layer of pyrolytic silicon carbide, which acts as a pressure vessel and provides containment for metallic fission products. The SiC layer is deposited by the thermal decomposition of methyltrichlorosilane $\left(\mathrm{CH}_{3} \mathrm{SiCl}_{3}\right.$ or MTS) in an excess of hydrogen. Certain fission products, notably silver and palladium, can cause degradation of the SiC during irradiation. The purpose of this study is to develop a quantitative data base to better understand noble-metal attack as well as to evaluate the relationship between SiC deposition conditions and noble-metal release.

The interaction between $\mathrm{SiC}$ and noble-metal fission product elements was investigated in the temperature range 1200 . to $1500^{\circ} \mathrm{C}$. Simulated high-burnup Triso-coated fuel particles were fabricated by impregnating $\mathrm{UO}_{2}$ microspheres with metallic $\mathrm{Ag}$ or $\mathrm{Pd}$ followed by coating them under systematically varied conditions. The coated particles were mounted in carbon disks and were annealed for $2000 \mathrm{~h}$ in a thermal gradient of $27.5^{\circ} \mathrm{C} / \mathrm{mm}$.

Metallographic examination revealed three modes of interaction: local attack of the SiC associated with nodules of $\mathrm{Ag}$ or $\mathrm{Pd}$, presence of free metal particles partway through the coating thickness where no visible penetration path existed, and accumulation of free metal along circumferential striations in coatings deposited at or below $1550^{\circ} \mathrm{C}$.

The rates of attack of $\mathrm{SiC}$ by $\mathrm{Ag}$ and $\mathrm{Pd}$ are strongly temperature dependent. The Pd attack rate increased slightly with increasing $\mathrm{SiC}$ coating rate, while SiC deposition temperature has little effect. Since the Pd attack rates during out-of-reactor annealing agree with rates measured in irradiated particles, it is likely that attack is controlled by grain boundary diffusion.

\section{INTRODUCTION}

Fuel microspheres for the High-Temperature Gas-Cooled Reactor (HTGR) are coated with several layers of pyrolytic carbon (PyC) and a layer of silicon carbide, as shown in Fig. 1. The low-density buffer PyC layer 

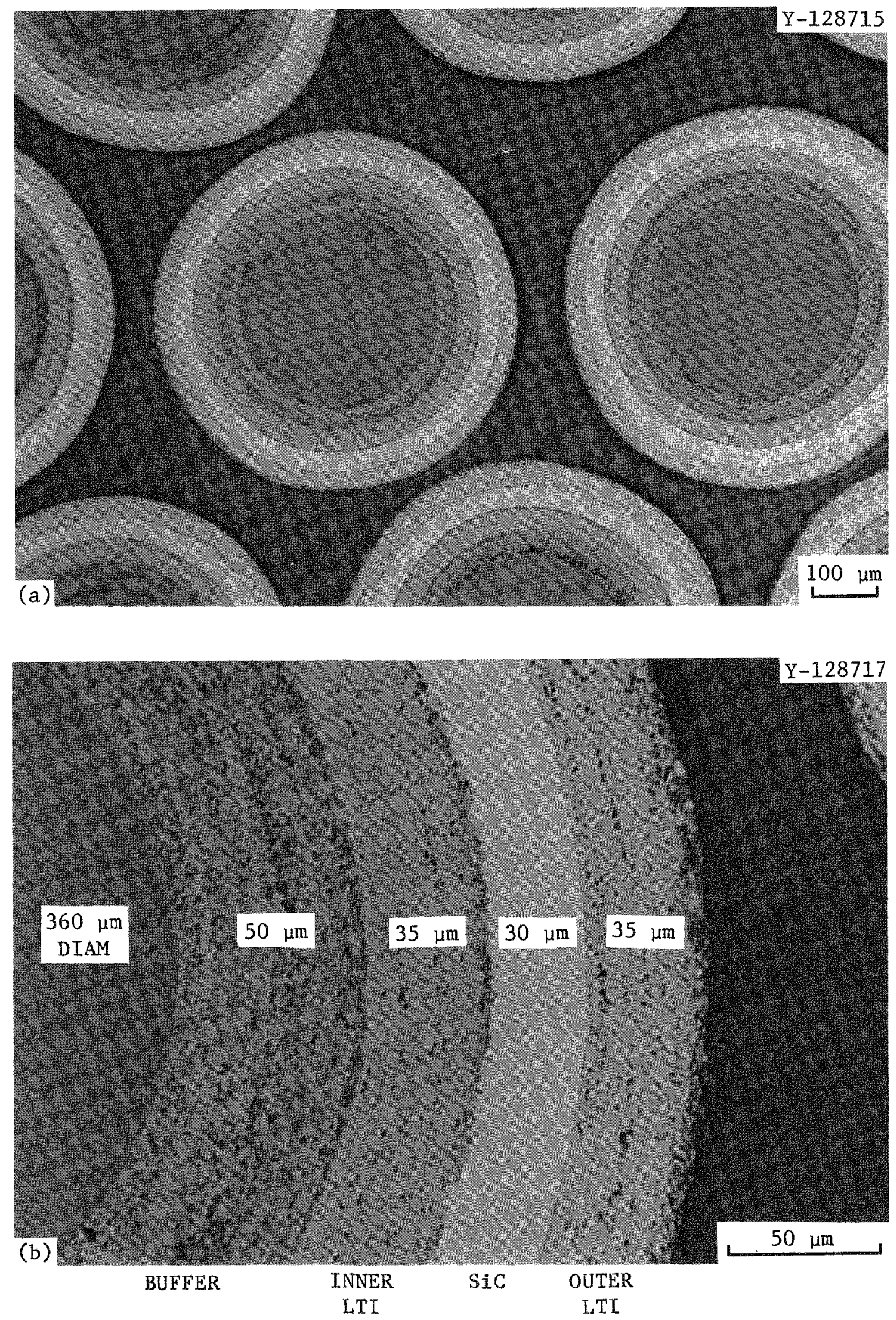

Fig. 1. Triso-Coated HTGR Fuel Particles. 
provides void volume for fission gas retention. The inner low-temperature isotropic (LTI) PyC layer provides mechanical strength to resist stresses generated by the fission gas pressure (typically several hundred times atmospheric pressure). The inner LTI layer also provides the containment for certain fission products that are produced in the kernel and that diffuse readily through the buffer layer. The SiC layer serves as a structural member (the complete fuel particle becomes a miniature pressure vessel) and is the primary containment for several fission products, namely, strontium, cesium, barium, and certain rare earths. These elements are the dominant solid products from the fission of $23 \mathrm{~b} U$ under standard conditions. The outer LTI PyC coating protects the SiC from mechanical damage during fabrication of the particles into carbon fuel rods.

It has been established that a SiC layer of nearly theoretical density provides adequate containment of fission products during irradiation of high-enriched uranium (HEU) ${ }^{*}$ fuels. 1 While low-enriched uranium $(\mathrm{LEU})^{*}$ and medium-enriched uranium (MEU) ${ }^{*}$ fuels are feasible from a neutronic standpoint, the greater amount of $238 \mathrm{U}$ causes a shift in fission yields toward the yield spectrum of ${ }^{239} \mathrm{Pu}$. The most important consequence of this is the increased yield of noble metals, especially silver and palladium. These elements are particularly agressive toward SiC at HTGR operating temperatures. Thus, a major goal of the present SiC development program is the optimization of the SiC coating for noble-metal retention.

To clarify the relationships between the deposition conditions and the coating microstructures and between the coating microstructures and noble-metal retention, 12 SiC coatings were deposited under systematically varied conditions of temperature and coating rate. For each SiC coating type, Biso-coated ${ }^{\dagger}$ kernels of $\mathrm{UO}_{2}, \mathrm{UO}_{2}$ plus $\mathrm{Ag}$, and $\mathrm{UO}_{2} \mathrm{plus} \mathrm{Pd}$ were included. The different coating types (taken pximarily from the pure $\mathrm{UO}_{2}$ kernels) were characterized by several techniques. The dependence of SiC coating microstructure and properties on deposition conditions was the

${ }^{*}$ Nominal enrichments are HEU, $93 \% 235 \mathrm{U} ; \mathrm{MEU}, 20$ to $40 \% 23 \mathrm{JU}$; and LEU, less than $10 \%{ }^{235} \mathrm{U}$.

That is, kernels coated with the buffer and inner LTI pyrocarbon 1ayers. 
subject of a previous report ${ }^{2}$ and is under continuing study. The present report describes the results of annealing each of the coated particle types in a thermal gradient to simulate conditions in an operating HTGR. The objective is to determine whether some SiC coatings are more resistant to noble-metal release than others deposited under slightly different conditions.

EXPERIMENTAL MATERIALS AND PROCEDURES

Fabrication of Simulated Fuel Microspheres

The first requirement of studying the interactions between SiC coatings and selected fission products without the difficulties associated with examining irradiated fuel was fabricating two batches of $\mathrm{UO}_{2}$ microspheres doped with $\mathrm{Ag}$ and $\mathrm{Pd}$, respectively. Idea11y, such experimental particles should be comparable in size to standard fuel microspheres and should contain a fine distribution of fission product. Furthermore, the particles must be reasonably spherical so that standard fluidized-bed coating practice can be used. Finally, it must be possible to Biso-coat the particles without volatilizing the fission product. Fabricating microspheres that fulfilled these requirements was a major experimental task.

Three batches of calcined uranium oxide microspheres produced by the chemical gelation process were obtained before sintering. One batch was sintered in the usual manner and was Biso-coated without the addition of any fission product elements. These particles, after coating with SiC, were annealed alongside those containing fission product elements to allow the study of microstructural changes resulting from thermal gradient annealing alone.

The second batch was sintered to about $60 \%$ of theoretical density by heating to $700^{\circ} \mathrm{C}$ in flowing hydrogen and then to $1200^{\circ} \mathrm{C}$ in argon. After cooling, the particles were infiltrated with aqueous silver nitrate solution, were rinsed, and were dried overnight at about $110^{\circ} \mathrm{C}$ in air. Some metallic Ag was visible on the particle surfaces at this stage. To fully reduce the $\mathrm{Ag}$ and remove any remaining $\mathrm{NO}_{\overline{3}}^{-}$, the particles were 
heated to $600^{\circ} \mathrm{C}$ in flowing hydrogen and held for $1 \mathrm{~h}$. To Biso-coat these particles the standard procedure* was modified. Before depositing the buffer coating, a thin carbon layer was deposited at about $800^{\circ} \mathrm{C}$. This prevented the Ag from boiling off when the buffer and inner LTI layers were deposited. The fine distribution of $\mathrm{Ag}$ within the Biso-coated kerne1 is shown optically in Fig. 2(a) and by electron microprobe analysis in Fig. 3.

The third batch was sintered to about $30 \%$ of theoretical density by heating to $700^{\circ} \mathrm{C}$ in flowing hydrogen followed by heating to $1000^{\circ} \mathrm{C}$ in flowing argon. The particles were infiltrated with aqueous $\mathrm{PdCl}_{2}$, then rinsed and dried as before. The dried spheres were heated to $600^{\circ} \mathrm{C}$ in flowing hydrogen, were held for $1 \mathrm{~h}$, and then were heated to $1400^{\circ} \mathrm{C}$ in argon for final sintering. (This sequence was possible because of the higher melting point of $\mathrm{Pd}$.) Some of the particles developed a rough surface during sintering, but this did not affect the subsequent coating steps. Figure 2(b) shows a Pd-doped kerne1, in which the Pd appears as extremely small round specks. An electron microprobe display of the Pd distribution is presented in Fig. 4.

The pertinent data for all three batches of kernels after Bisocoating are given in Table 1.

${ }^{*}$ Process procedure MET-CER-PP-12.

Table 1. Properties of $\mathrm{UO}_{2}$ Microspheres for Coating Experiments

\begin{tabular}{lccccccc}
\hline $\begin{array}{c}\text { Kernel } \\
\text { Type }\end{array}$ & $\begin{array}{c}\text { Fission Product } \\
\text { Concentration } \\
(\text { wt } \%)\end{array}$ & $\begin{array}{c}\text { Burnup } \\
(\% \text { FIMA }\end{array}$ & & \multicolumn{2}{c}{ Diameter, $b_{\mu \mathrm{m}}$} & & \multicolumn{2}{c}{ Thickness, $b_{\mu \mathrm{m}}$} \\
\hline $\mathrm{UO}_{2}$ & 0 & 0 & $411(45)$ & $497(33)$ & & $46(8)$ & $40(4)$ \\
$\mathrm{UO}_{2}+\mathrm{Ag}$ & 1.26 & $\sim 200 \mathrm{c}$ & $380(40)$ & $542(20)$ & & $45(5)$ & $45(5)$ \\
$\mathrm{UO}_{2}+\mathrm{Pd}$ & 0.54 & $\sim 10$ & $360(50)$ & $523(35)$ & & $45(6)$ & $38(4)$ \\
\hline
\end{tabular}

$a_{\text {FIMA }}=$ fissions per initial metal atom.

$b_{\text {Numbers }}$ in parentheses are \pm deviations.

${ }^{C}$ The Ag-doped kernels contained substantially more Ag than would a fuel particle at end of life. This occurred because it was impossible to accurately predict the efficiency of the infiltration-reduction process. 

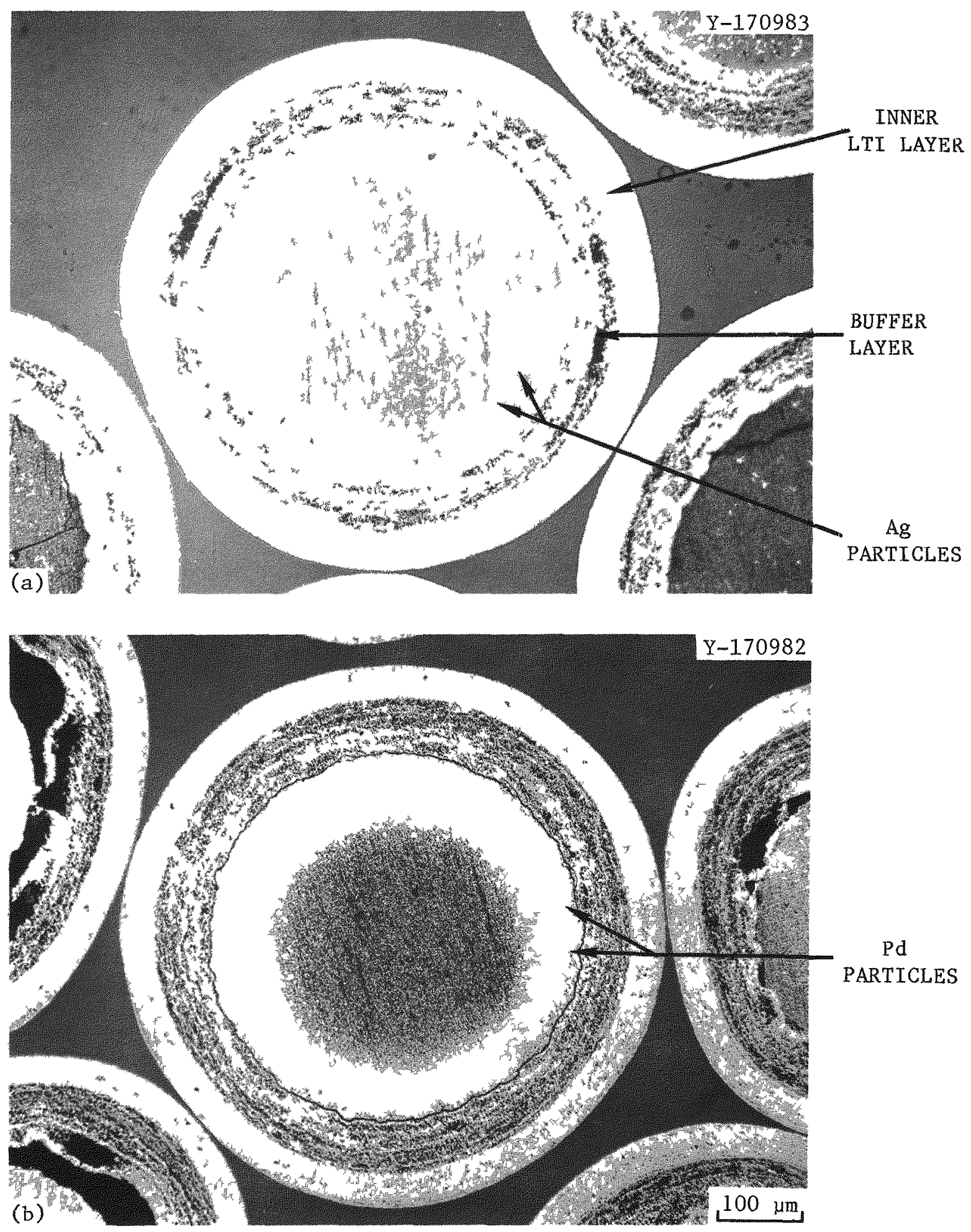

Fig. 2. Optical Macrographs of B1so-Coated $\mathrm{JO}_{2}$ Microspheres Doped with Fission Product Elements. (a) $\mathrm{UO}_{2}$ plus $\mathrm{Ag}$. (b) $\mathrm{UO}_{2}$ plus Pd. 

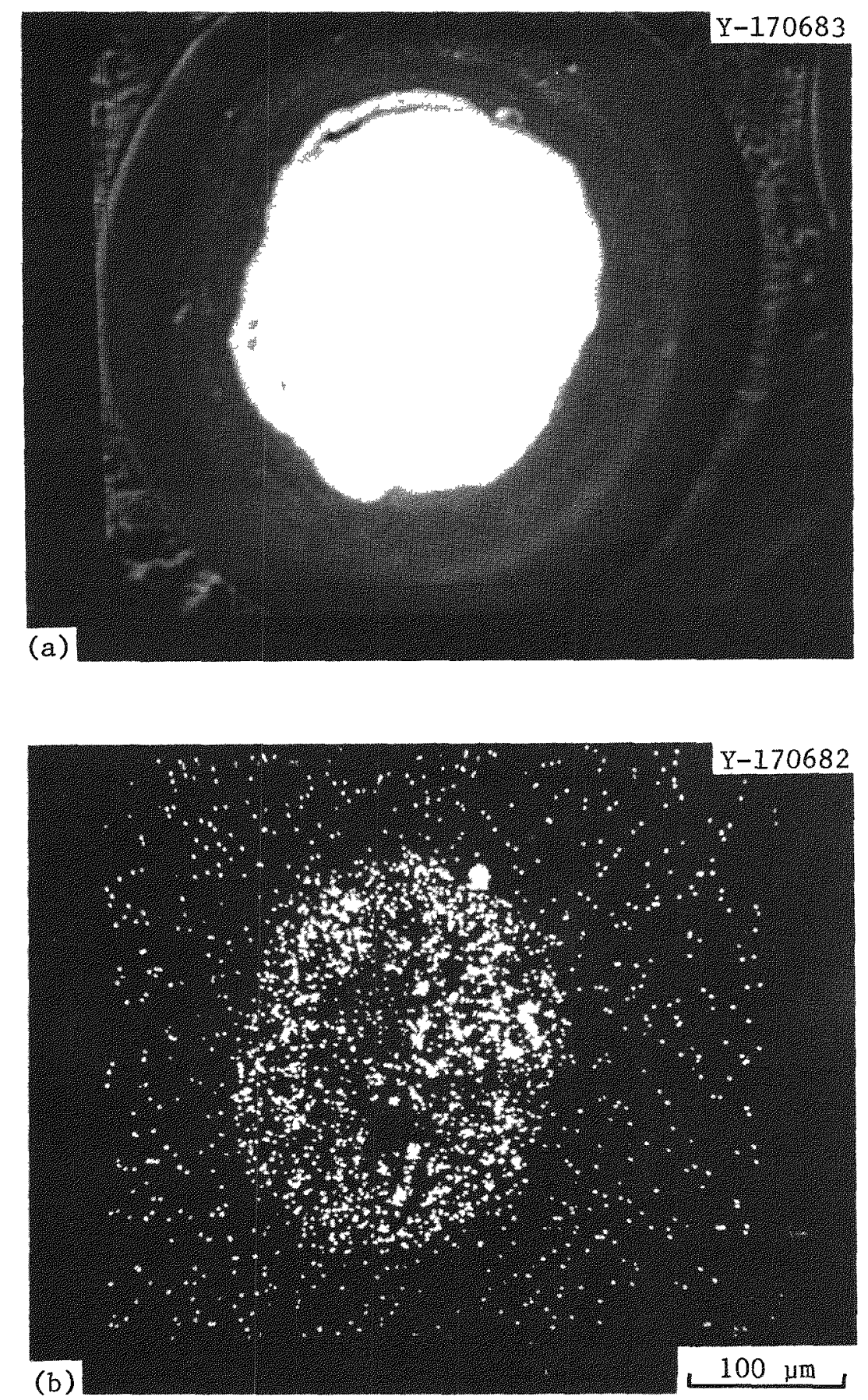

Fig. 3. Electron Microprobe Displays of Biso-Coated $\mathrm{UO}_{2}$ Microspheres Doped with Ag. (a) Backscattered electron image. (b) $\mathrm{Ag} L \alpha$ image. 

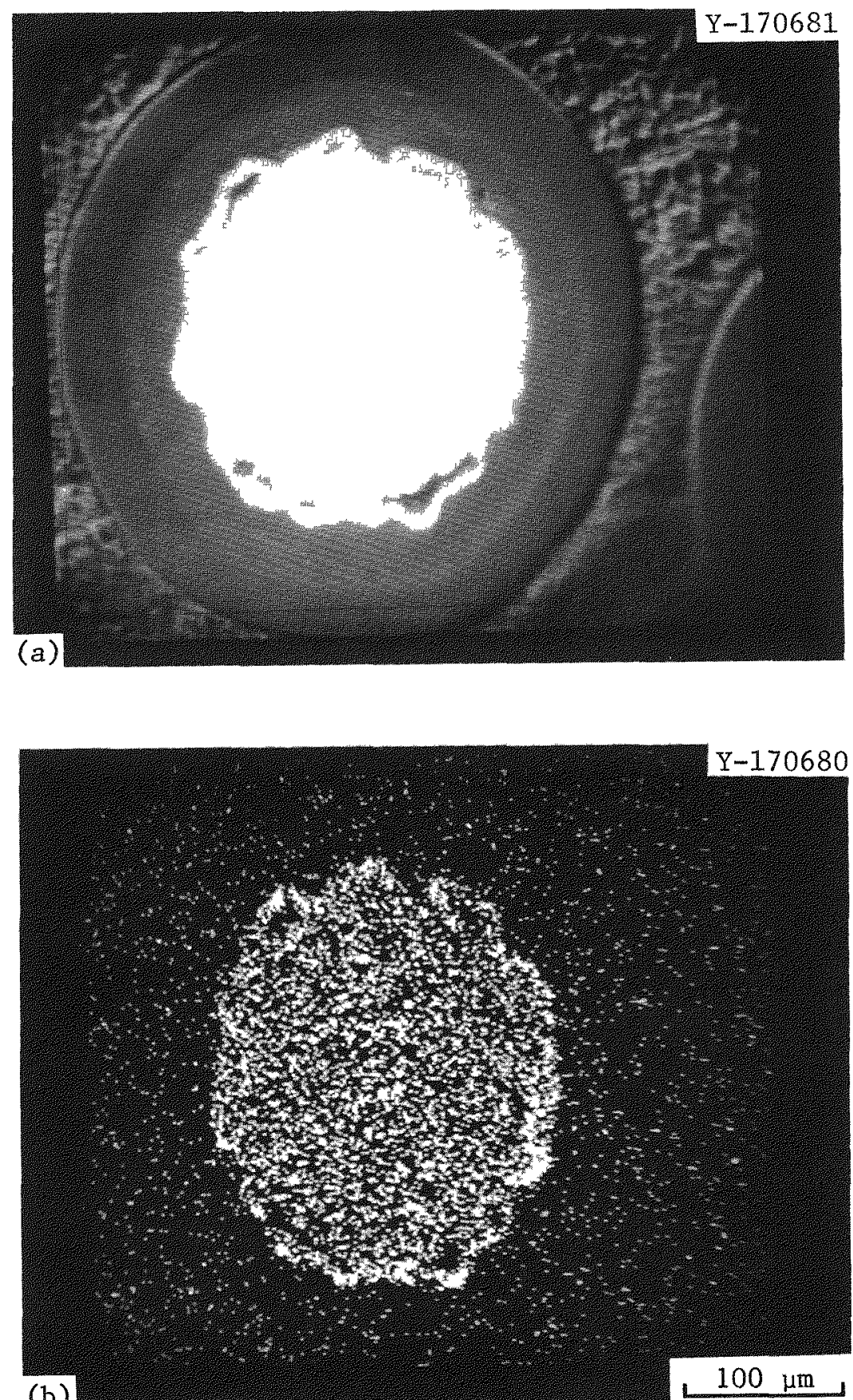

Fig. 4. Electron Microprobe Displays of Biso-Coated $\mathrm{UO}_{2}$ Microspheres Doped with Pd. (a) Backscattered electron image. (b) Pd $L \alpha$ image. 
Deposition of SiC Coatings

Coatings were deposited by thermal decomposition of methyltrichlorosilane $\left(\mathrm{CH}_{3} \mathrm{SiCl}_{3}\right.$ or MTS $)$ in an excess of hydrogen. Details of the coating apparatus and procedure are given elsewhere. ${ }^{3}$ In the present study we investigated 12 sets of coating conditions. For each set the three different kernel types were coated separately. Thus, a total of 36 coating runs were made. Table 2 sumarizes the data for all coating runs used in this study.

We assumed that coatings deposited on all types of kernels under nearly identical conditions would have similar structure and properties. To verify this, coating samples were removed from several batches that contained $\mathrm{Ag}$ or $\mathrm{Pd}$, and their densities were compared with those of coatings deposited on $\mathrm{UO}_{2}$ kernels under corresponding conditions. As Table 2 shows, the initial assumption was verified by the results of density measurements.

Annealing Tests

To simulate thermal conditions in an HTGR, the experimental particles were annealed in a therral zradient furnace. The apparatus and technique are described in detail by Lindemer and Pearson ${ }^{4}$ and may be briefly summarized as follows. Approximately 20 particles from each of the 36 coating batches were mounted in carbon disks. After the disks were cured and heat-treated, they were cemented into graphite plates, which held them in the gradient furnace. Since each plate had provision for 3 disks, 12 plates were used, 1 for each set of coating conditions. Each plate thus contained samples of the three types of particles $\left(\mathrm{UO}_{2}, \mathrm{UO}_{2} \mathrm{plus} \mathrm{Ag}\right.$, and $\mathrm{UO}_{2}$ plus $\mathrm{Pd}$ ), all coated under the same conditions. The sample holder is i11ustrated in Fig. 5.

The operating conditions of the gradient furnace were set to provide a thernal gradient of about $27.5^{\circ} \mathrm{C} / \mathrm{mm}$ across the diameter of each disk. The hot side was held at $1500^{\circ} \mathrm{C}$, and since the particles were spread over a distance of about $10 \mathrm{~mm}$, individual particle temperatures ranged from 
Table 2. Summary of Experimental SiC Coating Runs

\begin{tabular}{|c|c|c|c|c|}
\hline $\operatorname{Batch}^{\alpha}$ & Run & $\begin{array}{l}\text { Deposition } \\
\text { Temperature } \\
\left({ }^{\circ} \mathrm{C}\right)\end{array}$ & $\begin{array}{l}\text { Coating } \\
\text { Rate } \\
(\mathrm{m} / \mathrm{min})\end{array}$ & $\begin{array}{c}\text { SiC } \\
\text { Density } \\
\mathrm{Mg} / \mathrm{m}^{3}\end{array}$ \\
\hline $\mathrm{D}-1$ & $\mathrm{SC}-483$ & 1500 & 0.42 & 3.208 \\
\hline$D-2$ & 484 & 1550 & 0.40 & 3.212 \\
\hline$D-3$ & 485 & 1650 & 0.43 & 3.218 \\
\hline$D-4$ & 487 & 1700 & 0.42 & 3.197 \\
\hline$D-5$ & 472 & 1500 & 0.70 & 3.190 \\
\hline$D-6$ & 475 & 1550 & 0.75 & 3.207 \\
\hline$D-7$ & 477 & 1650 & 0.71 & 3.203 \\
\hline $\mathrm{D}-8$ & 475 & 1700 & 0.50 & 3.195 \\
\hline$D-9$ & 479 & 1500 & 1.20 & 3.156 \\
\hline$D-10$ & 473 & 1550 & 1.01 & 3.195 \\
\hline$D-11$ & 480 & 1650 & 0.95 & 3.207 \\
\hline$D-12$ & 481 & 1700 & 1.06 & 3.206 \\
\hline $\mathrm{Ag}-1$ & 508 & 1500 & 0.40 & \\
\hline $\mathrm{Ag}-2$ & 511 & 1550 & 0.39 & \\
\hline $\mathrm{Ag}-3$ & 521 & 1650 & 0.32 & \\
\hline $\mathrm{Ag}-4$ & 518 & 1700 & 0.37 & \\
\hline$A g-5$ & 509 & 1500 & 0.70 & \\
\hline $\mathrm{Ag}-6$ & 505 & 1550 & 0.64 & 3.207 \\
\hline $\mathrm{Ag}-7$ & 519 & 1650 & 0.73 & \\
\hline $\mathrm{Ag}-3$ & 507 & 1700 & 0.63 & \\
\hline $\mathrm{Ag}-9$ & 510 & 1500 & 1.24 & \\
\hline $\mathrm{Ag}-10$ & 512 & 1550 & 1.19 & \\
\hline $\mathrm{Ag}-11$ & 513 & 1650 & 0.91 & \\
\hline $\mathrm{Ag}-12$ & 514 & 1700 & 1.16 & \\
\hline$P d-1$ & 499 & 1500 & 0.44 & 3.208 \\
\hline$P d-2$ & 500 & 1550 & 0.39 & \\
\hline$P d-3$ & 522 & 1650 & 0.40 & \\
\hline $\mathrm{Pd}-4$ & 502 & 1700 & 0.33 & \\
\hline$P d-5$ & 488 & 1500 & 0.79 & \\
\hline$P d-6$ & 489 & 1550 & 0.78 & \\
\hline $\mathrm{Pd}-7$ & 492 & 1650 & 0.50 & \\
\hline$P d-8$ & 493 & 1700 & 0.79 & \\
\hline$P d-9$ & 494 & 1500 & 1.04 & 3.184 \\
\hline$P d-10$ & 498 & 1550 & 1.03 & \\
\hline$P d-11$ & 496 & 1650 & 0.97 & 3.207 \\
\hline$P d-12$ & 497 & 1700 & 1.29 & \\
\hline
\end{tabular}

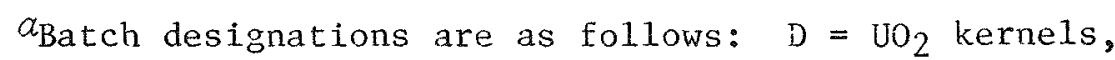
$\mathrm{Ag}=\mathrm{UO}_{2}+\mathrm{Ag}$ kernels, and $\mathrm{Pd}=\mathrm{UO}_{2}+\mathrm{Pd}$ kernels. 
ORNL DWG $75-14996$

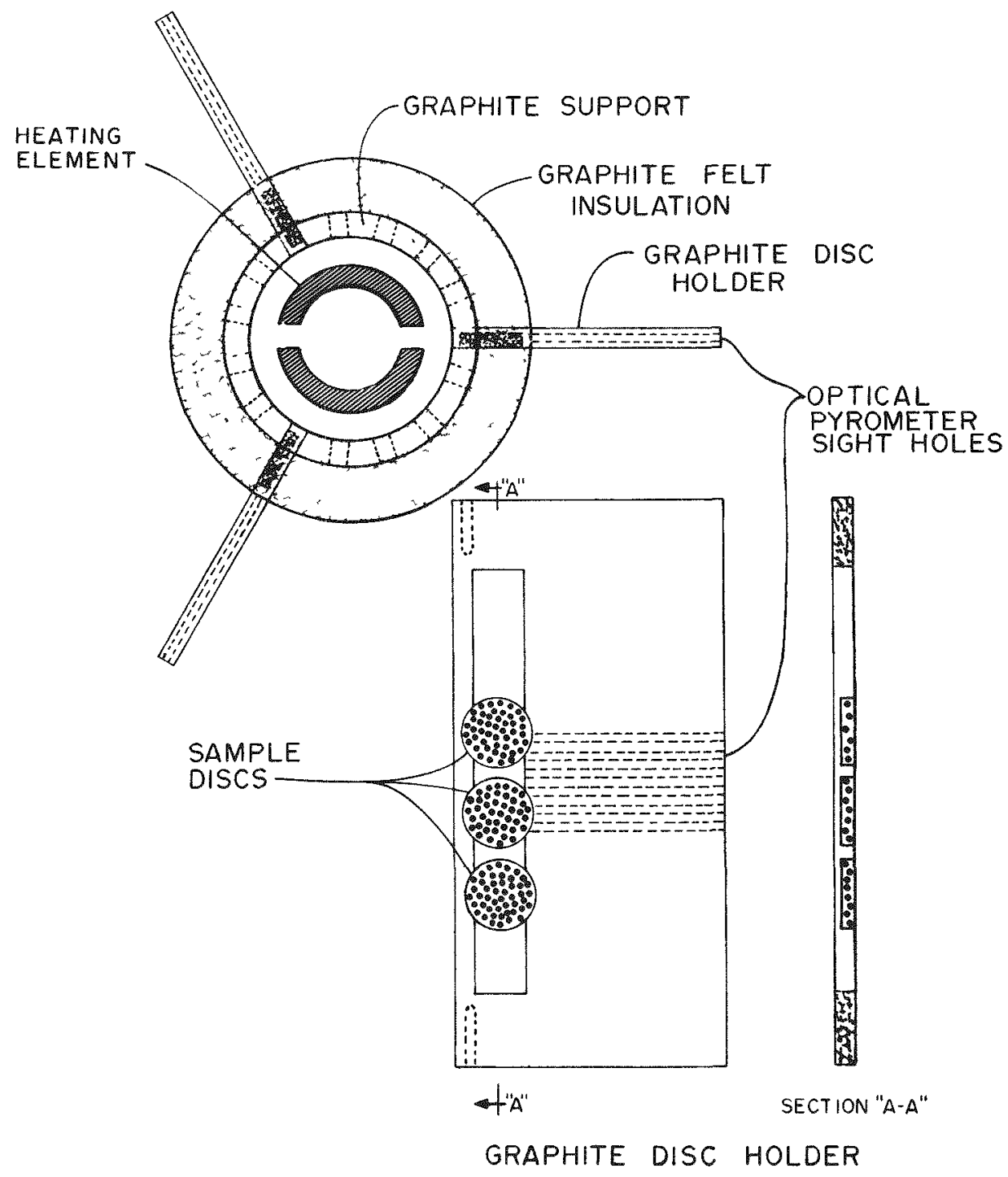

Fig. 5. Graphite Holder Used to Support Experimental Particles for Annealing in Thermal Gradient Furnace.

about 1500 to about $1225^{\circ} \mathrm{C}$. Exact positions relative to the hot face were measured on radiographs of the completed assemblies. The exact temperature of each particle could thus be calculated subsequently.

The plates were removed from the furnace and radiographed after 400 and $1024 \mathrm{~h}$ of annealing to monitor any changes such as kernel migration or gross coating attack. After a total of $2000 \mathrm{~h}$ of annealing, the disks were removed and prepared for metallographic examination. 
RESULTS AND DISCUSSION

Urania Kernels

The coated particles that did not contain fission product elements showed no SiC degradation after $2000 \mathrm{~h}$ of annealing in the thermal gradient furnace. Some kernels, particularly those at 1450 to $1500^{\circ} \mathrm{C}$, exhibited slight shrinkage. This evidently resulted from further sintering during the annea1. Even in these cases the SiC and PyC layers were unaffected.

Urania Kernels Containing Palladium

The coated particles containing Pd showed several effects:

1. Local spots were attacked in all batches, particularly on the cold sides of the particles. The attack was characterized by partial penetration of the SiC layer, generally associated with a buildup of Pd at the SiC-inner LTI interface. Free Pd and possibly an unidentified reaction product usually formed a nodule at the attack site, and the area was nearly always optically anisotropic. The overall appearance of the reaction zone, shown in Fig. 6, is identical to that of similar attack seen in ixradiated microspheres. 5

2. Small bright specks that appear to be Pd occurred at some distance into the coating thickness in sone specimens where no localized attack could be seen. We do not know whether these are accumulations following solid-state diffusion or protuberances on the surface of an attack nodule that is too far below or above the plane of polish to be visible.

3. Metallic spots (probably Pd) distributed along circumferential striations in the SiC were seen in coatings deposited at $1500^{\circ} \mathrm{C}$. A typical view of this phenomenon is shown in Fig. 7.

We attempted to quantify the Pd attack for comparison with irradiation results. Each disk was examined optically, and particles were selected that had visible nodules of attack. The nodules were photographed at 1000x, and each particle was located on the appropriate 

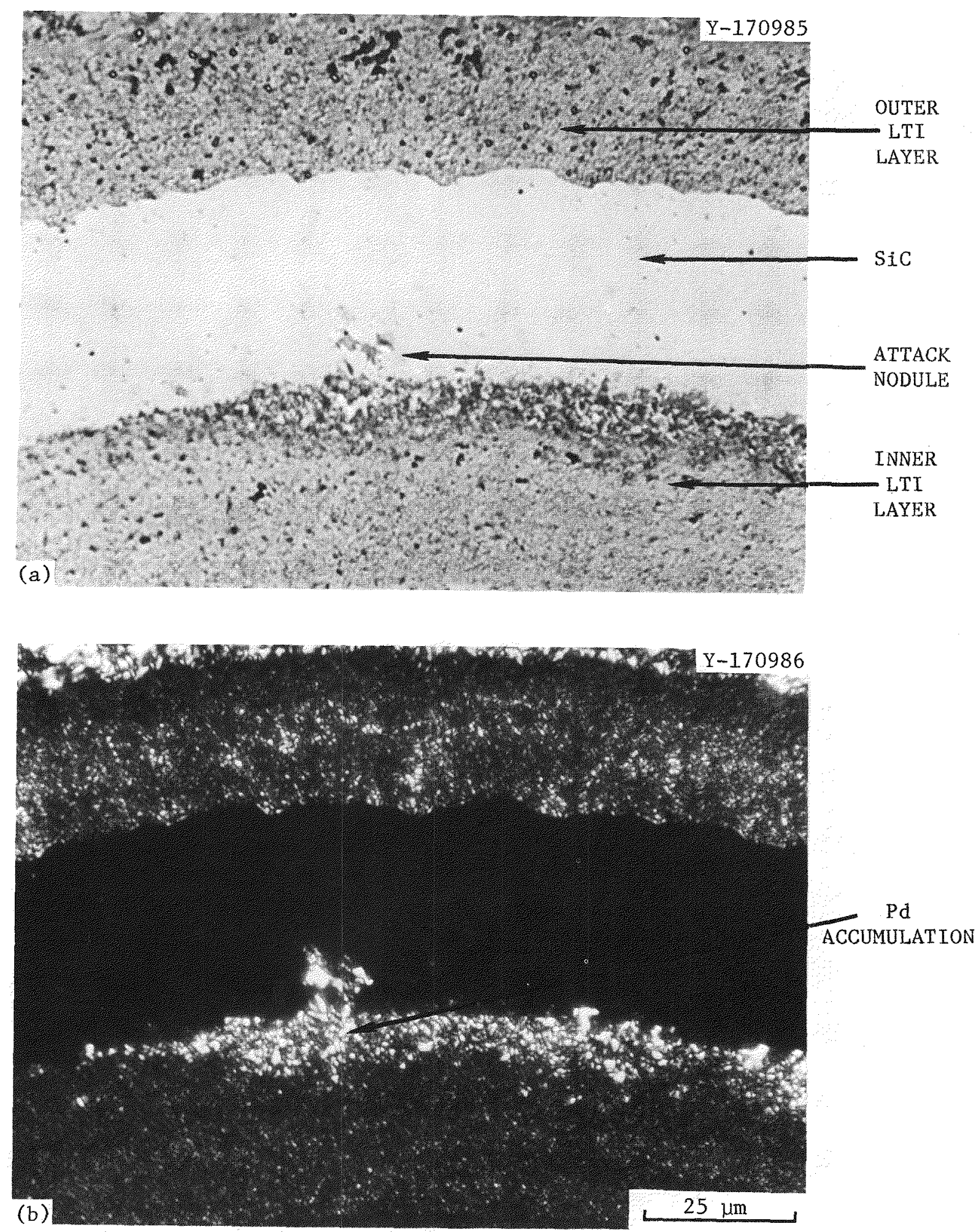

Fig. 6. Site of Pd Attack of SiC After Thermal Gradient Anneal. (a) Bright field. (b) Polarized light. 


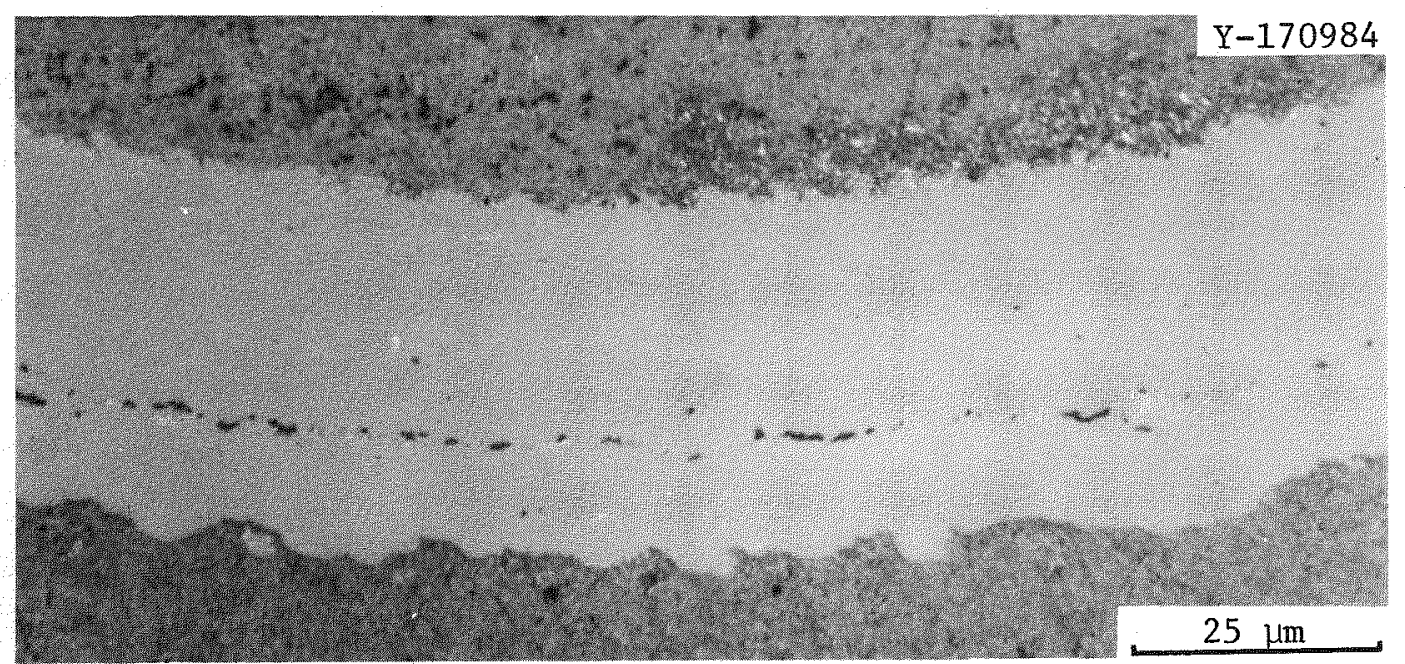

Fig. 7. Metallic Specks (White Spots) Distributed Along Circumferential Striations in a SiC Coating Deposited at $1550^{\circ} \mathrm{C}$. These spots are believed to be $\mathrm{Pd}$.

radiograph (to determine its exact temperature during the annea1). Depth of penetration into the $\mathrm{SiC}$ was measured to $\pm 0.5 \mu \mathrm{m}$, and penetration rate was calculated by dividing by $2000 \mathrm{~h}$. The Appendix lists the results of quantitative metallography. The data were plotted according to the Arrhenius relation

$$
P=A \exp (-Q / R T)
$$

where

$$
\begin{aligned}
& P=\text { rate of penetration into } \mathrm{SiC} ; \\
& A=\text { preexponential constant; } \\
& Q=\text { activation energy for the rate-controlling process; } \\
& R=\text { gas constant, } 8.314 \mathrm{~J} / \mathrm{mol} \mathrm{K} ; \\
& T=\text { absolute temperature. }
\end{aligned}
$$

Figure 8 shows the data points from this study and, for comparison, the best fit line from irradiation studies ${ }^{5}$ given by $A=46.2 \mu \mathrm{m} / \mathrm{h}$ and $Q=1.358 \times 10^{5} \mathrm{~J} / \mathrm{mol}$. Taking the data from this study only, the activation energy is calculated to be $Q_{P d}=0.950 \times 10^{5} \mathrm{~J} / \mathrm{mol}$. 


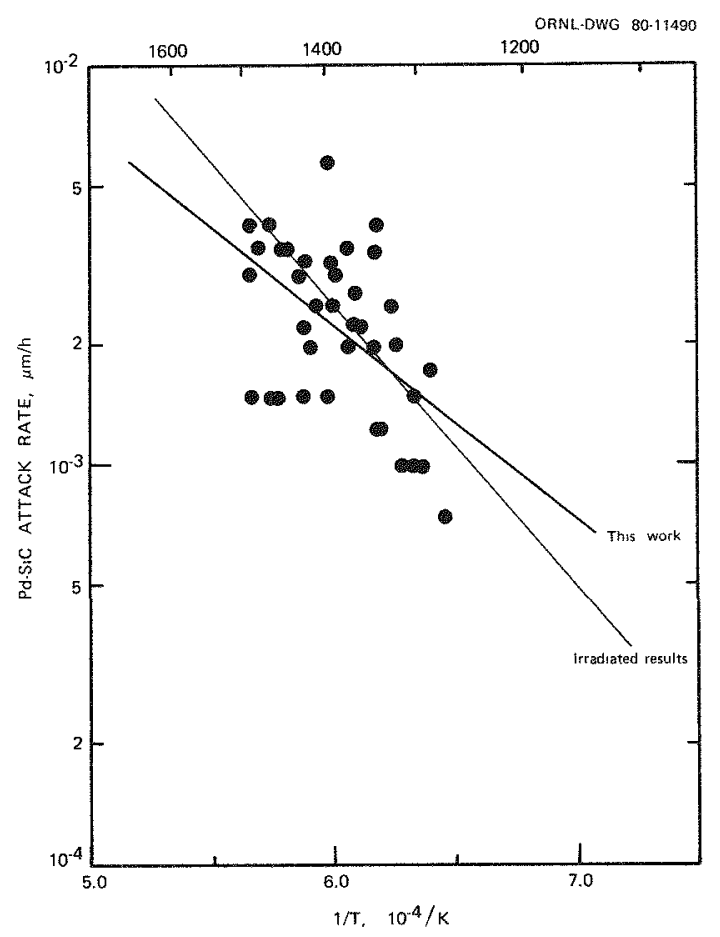

Fig. 8. Arrhenius Plot of Attack Rate of SiC by the Fission Product Element Pd. The activation energy obtained from the slope of the "best fit" line (using a linear regression) is about $95 \mathrm{~kJ} / \mathrm{mol}$. The line obtained from irradiation experiments passes through these data also.

Considering the experimental uncertainty, ${ }^{*}$ the agreement with irradiation results is quite good. It should be noted that irradiation data have a temperature uncertainty of about $\pm 100^{\circ} \mathrm{C}$ for each particle. For out-of-reactor data the error is only about $\pm 10^{\circ} \mathrm{C}$.

The best fit line from irradiation data passes directly through the cluster of points from this work, indicating that if the attack is diffusion controlled, it probably results from grain boundary diffusion. The reason for this is illustrated schematically in Fig. 9. An Arrhenius plot for diffusion in a polycrystalline material often exhibits a change of slope, which is interpreted as a change of mechanism from vacancy diffusion to grain boundary diffusion. During irradiation the vacancy concentration at low to moderate temperatures is substantially greater than

* The accurate measurement of penetration requires that the plane of polish intersect an attack site close to its maximum depth (an unrealistic expectation). Thus, the measured value is at most the true value and generally less. Consequently, the highest values are probably more accurate. 


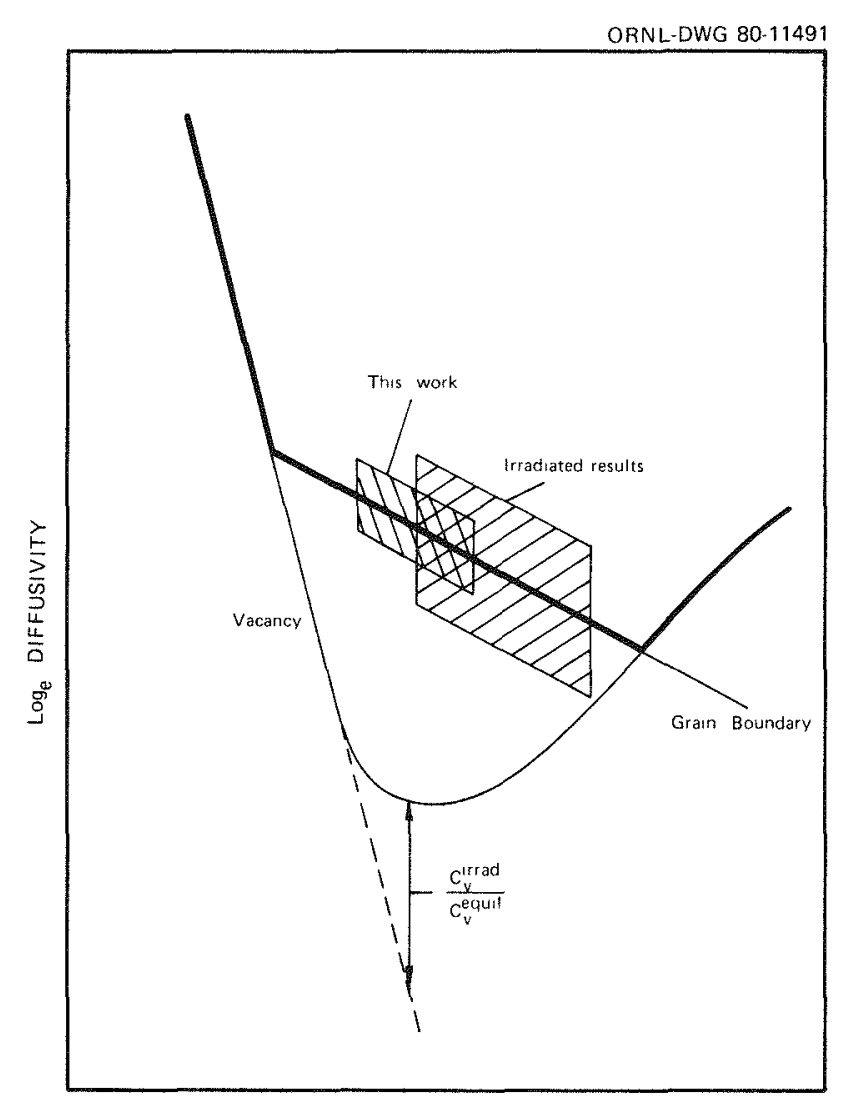

INVERSE TEMPERATURE

Fig. 9. Schematic Arrhenius Plot for Diffusion in a Polycrystalline Material, Showing that Irradiation Causes Enhanced Vacancy Diffusion at Lower Temperatures. In principle, grain boundary diffusion is not affected. The dominant process at any temperature is that for which the diffusivity is highest (indicated by bold curve). The presumed locations of annealing experiments and irradiations are indicated. The ratio of vacancy concentration during irradiation ( $C$ irrad) to the equilibrium value ( $C$ Vquil) is strongly temperature dependent, as shown.

the equilibrium value, while the activation energy for vacancy motion is essentially constant. Thus, the vacancy contribution to the Arrhenius curve is displaced upward and can increase low-temperature diffusivities by several orders of magnitude. 6 In principle, the grain boundary "leg" is unaffected by irradiation. If vacancy diffusion were dominant in the temperature range of interest here, one would expect the irradiation data to be shifted very noticeably upward relative to the out-of-reactor data. Since that did not occur, it is probable that grain boundary diffusion is the dominant mechanism of Pd attack and transport into the SiC layer. It should also be noted that the activation energy for tracer diffusion of $\mathrm{Si}$ in a-SiC has been determined $^{7}$ and is about 6 to 7 times greater than the 
activation energy determined here for Pd attack. And since Pd is larger than Si, the activation energy for its motion through the SiC lattice is probably yet greater. (The difference in activation energy for diffusion in $\beta$ - vs $\alpha-S i C$ is not known but is probably small compared with the factor of 6 or 7 noted above.)

The apparent accumulation of $\mathrm{Pd}$ in coating striations is particularly interesting. Recent transmission electron microscopic (TEM) studies ${ }^{2}$ have shown the striations to consist of bands of porosity separated by bands of small equiaxed grains. Structurally, this must be considered a coating defect. However, it may have a beneficial aspect if it delays release of noble metals by giving them a place to collect. In this sense the striations might be analogous to the buffer PyC layer. We are planning TEM studies to examine some of these coatings after exposure, to determine the phases present in the attack nodules and in the striations, and to further clarify the role of grain boundaries for Pd transport.

The effect of deposition variables on rates of $\mathrm{Pd}$ attack is weak. Figure 10 shows the $\mathrm{Pd}$ attack rates for all 12 coating batches as a

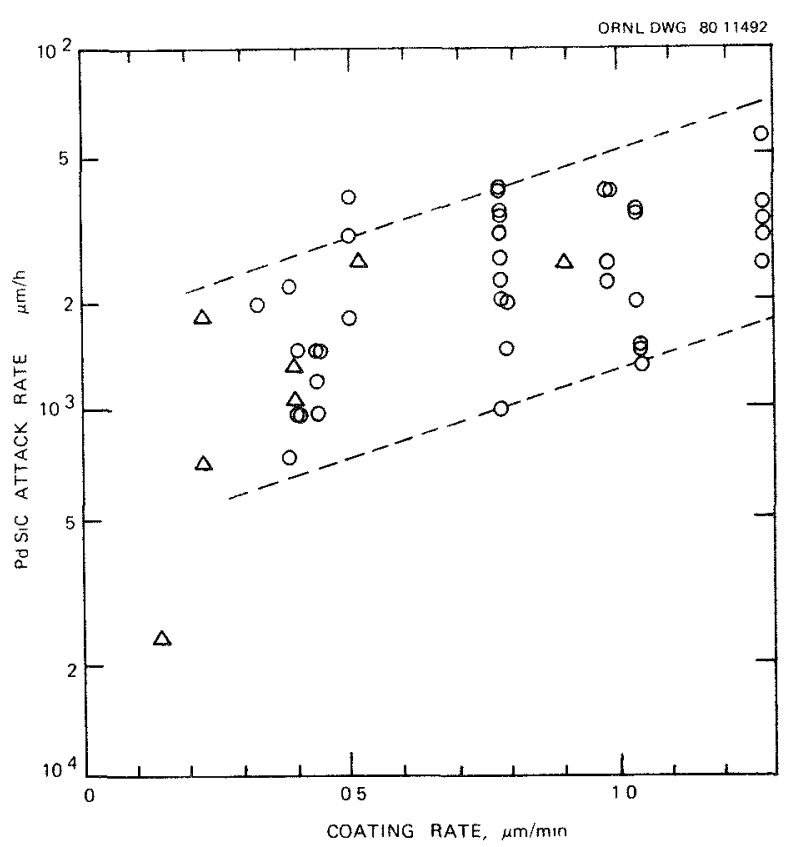

Fig. 10. Palladium Attack Rate as a Function of SiC Coating Rate. Triangle points indicate results of irradiation experiments. [Source of irradiation data: T. N. Tiegs, Fission Product Pd-SiC Interaction in Irradiated Coated Fuel Particles, ORNL/TM-7203 (April 1980). Note that a typographical error in this source indicated coating rate in micrometers per hour. Micrometers per minute is the correct unit in both studies.] 
function of coating rate. Comparisons are difficult since the individual particle temperatures vary somewhat and not enough data exist to select a narrow temperature range for comparison. Nonetheless, the data indicate an increase in $P d$ attack rate with increasing coating rate. This relationship was also suggested by irradition results, which are included in the figure for comparison.

The correlation between attack rates and deposition temperature is even less obvious and changes form depending on the annealing temperature selected for comparison. This indicates that more data are needed, and for that reason the plots are not presented here.

The relation between $P d$ attack rates and small-angle $x$-ray scattering (SAXS) measurements is just now being investigated and will be included in a future report. It has been suggested ${ }^{8}$ that coatings with low SAXS intensity might be more resistant to noble-metal attack.

Urania Kernels Containing Silver

In general, the Ag-doped particles exhibited damage to the SiC layer after annealing. The three modes of interaction seen in Pd-doped particles were also observed in Ag-doped specimens. As a rule there was greater penetration by $\mathrm{Ag}$ than by $\mathrm{Pd}$. This probably results from the following causes:

1. Silver melts at $960^{\circ} \mathrm{C}$, and thus at 1300 to $1500^{\circ} \mathrm{C}$ one would expect considerable $\mathrm{Ag}$ vapor pressure and increased mobility. On the other hand, Pd was not even at its melting point $\left(1550^{\circ} \mathrm{C}\right)$ in the temperature range used in this experiment.

2. The Ag-doped particles contained more free metal than did the Pddoped particles. This made individual attack sites larger and more readily observed.

Figure 11 shows the data for Ag penetration into the SiC layer. The apparent activation energy for this process is $Q_{\mathrm{Ag}}=1.16 \times 10^{5} \mathrm{~J} / \mathrm{mol}$. In Fig. 11 the "best fit" line from the Pd data is shown for comparison. Since the activation energies are nearly equal, it is probable that $\mathrm{Ag}$ attack is also controlled by diffusion along grain boundaries (or perhaps some other interface). 


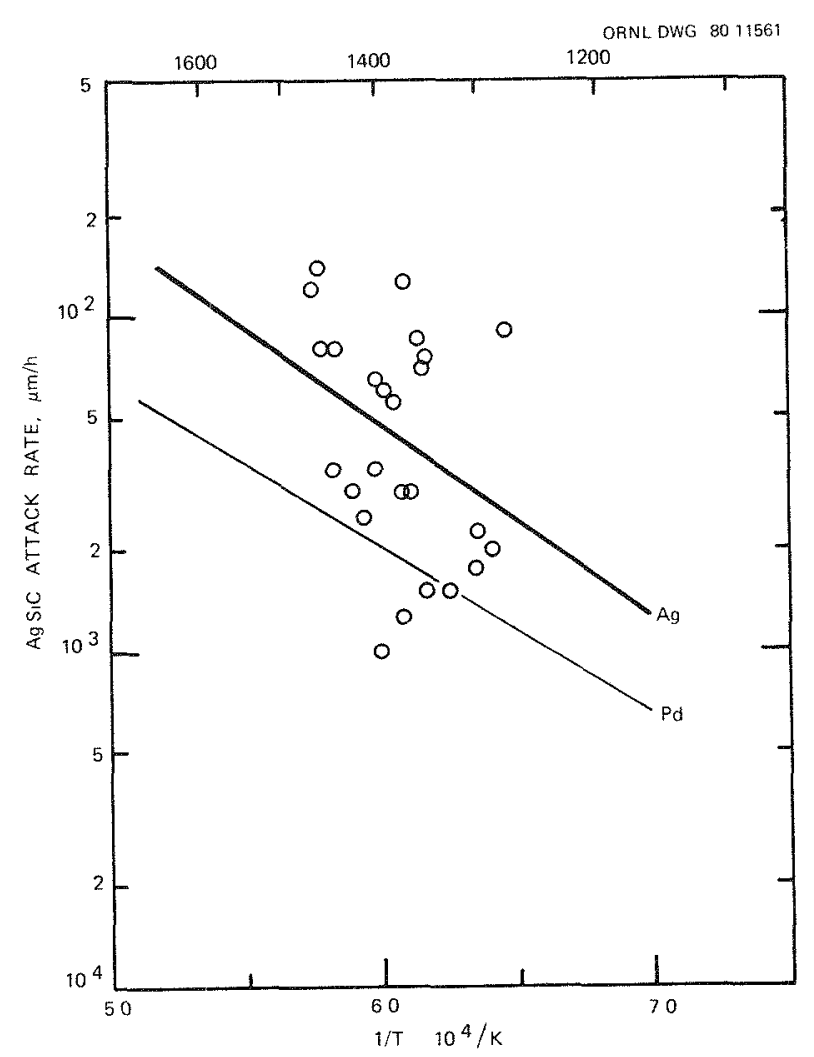

Fig. 11. Arrhenius Plot for the Attack of SiC by Ag. The best fit line for $\mathrm{Pd}$ attack is shown for comparison. The activation energy for $\mathrm{Ag}$ attack is $116 \mathrm{~kJ} / \mathrm{mol}$.

Transmission electron microscopy and electron microprobe analyses will be used to attempt to identify critical diffusion paths for $\mathrm{Ag}$ in the SiC layer as well as to study the role of microscopic voids in the coatings. Further optical metallography will be done to increase the data base and, it is hoped, to decrease the scatter present. At that time the effects of coating process variables will be investigated along with the relationship between SAXS intensity and $\mathrm{Ag}$ retention. The results of quantitative metallography on Ag-doped particles are given in the Appendix.

\section{CONCLUSTONS}

1. Noble-metal attack can be simulated and studied quantitatively by thermal gradient annealing of particles doped with fission product elements, provided the temperatures used are reasonably close to those expected during reactor operation. 
2. The fission product elements $\mathrm{Ag}$ and Pd attack the SiC layer on HTGR fuel particles. Three modes of interaction are observed: 1ocalized attack in small "nodules," specks of free metal surrnunded by intact SiC, and free metal accumulations in the circunferential striations present in some coatings.

3. The $\mathrm{Pd}$ and $\mathrm{Ag}$ appear to be collecting in coating striations (defects in the deposition process). These striations may therefore have a beneficial effect in reducing or halting $\mathrm{Pd}$ or Ag migration through the SiC layer.

4. The rate of attack of SiC by Pd observed in out-of-reactor annealing studies is in general agreement with the results of irradiation experiments. The rate of penetration by $\mathrm{Ag}$ appears to be more rapid than attack by $\mathrm{Pd}$, but both processes have about the same activation energy.

5. The rate of $\mathrm{SiC}$ attack by $\mathrm{Ag}$ or $\mathrm{Pd}$ at no greater than $1500^{\circ} \mathrm{C}$ appears to be controlled by diffusion along grain boundaries or some other enhanced-mobility path. For this reason attack rates derived from very high temperature measurements (where vacancy diffusion predominates) cannot safely be extrapolated to pertinent irradiation temperatures.

6. The rate of $P d$ attack increases with increasing exposure temperature. Higher SiC coating rates cause a slight increase in attack rate, while deposition temperature appears to have little effect.

7. More data are needed, particularly for Ag attack rates. This will increase confidence in the data and possibly allow the effects of deposition variables to be more accurately determined.

\section{ACKNOWLEDGMENTS}

The author would like to thank the following for their contributions to this work: R. L. Heestand suggested the infiltration technique, J. W. Geex and C. Hamby performed the coating runs, and J. W. Geer fabricated the annealing specimens. E. V. Davis and the late W. J. Mason did the radiography. R. L. Pearson assisted with the annealing procedure. W. H. Warwick and G. C. Marsh prepared metallographic samples and took photomicrographs. P. F. Tortorelli and D. N. Braski reviewed the 
manuscript. B. G. Ashdown edited the report, and final report preparation was done by $\mathrm{P}$. T. Thornton of the Metals and Ceramics Division Reports office.

\section{REFERENCES}

1. T. D. Gulden and H. Nickel, "Preface, Coated Particle Fuels," Nucl. Technol. 35: 206-13 (September 1977).

2. R. J. Lauf and D. N. Braski, Dependence of SiC Coating Properties on Deposition Parameters - PreZiminary Report, ORNL/TM-7209 (Apri1 1980).

3. R. J. Lauf, D. N. Braski, and V. J. Tennery, Characterization of SiC Coatings on HTGR Fuel Particles: Preliminary Report, ORNL/TM-6940 (August 1979).

4. T. B. Lindemer and R. L. Pearson, "Kernel Migration for HTGR Fuels from the System Th-U-Pu-C-O-N," J.Am. Ceram. Soc. 60(1-2): 5-14 (1977).

5. T. N. Tiegs, Fission Product Pd-SiC Interaction in Irradiated Coated Particle Fuels, ORNL/TM-7203 (April 1980).

6. P. W. Levy, "Physical Properties of Irradiated Ceramic Materials," pp. 27-32 in Nuclear Science and Technology for Ceramists, Proceedings of a Symposium, Aprit 7-12, 1966, National Bureau of Standards, Washington, D.C., May 1967.

7. J. D. Hong, "Self-Diffusion of Carbon-14 and Silicon-30 in Alpha Silicon Carbide Single Crystals," Ph.D. Thesis, N.C. State University at Raleigh, 1978.

8. P. Krautwasser and E. Wallura, "SiC Coating Characterization by Small Angle X-ray Scattering," paper presented at ANS Winter Meeting, San Francisco, Nov. 11-15, 1979. 
APPENDIX 
Table Al. Quantitative Metallography Results for $\mathrm{UO}_{2}+\mathrm{Pd}$ Coated Particles

\begin{tabular}{|c|c|c|c|}
\hline Batch & Particle & $\begin{array}{c}\text { Temperature } \\
\left({ }^{\circ} \mathrm{C}\right)\end{array}$ & $\begin{array}{c}\text { Attack Rate } \\
(\mu \mathrm{m} / \mathrm{h})\end{array}$ \\
\hline$P d-1$ & $\begin{array}{l}2 \\
3 \\
1 \\
4\end{array}$ & $\begin{array}{l}1335 \\
1305 \\
1460 \\
1300\end{array}$ & $\begin{array}{l}1.25 \\
1.50 \\
1.50 \\
1.00\end{array}$ \\
\hline $\mathrm{Pd}-2$ & $\begin{array}{r}6 \\
21\end{array}$ & $\begin{array}{l}1425 \\
1275\end{array}$ & $\begin{array}{l}2.25 \\
0.75\end{array}$ \\
\hline$P d-3$ & $\begin{array}{l}3 \\
1 \\
2\end{array}$ & $\begin{array}{l}1305 \\
1470 \\
1310\end{array}$ & $\begin{array}{l}1.00 \\
1.50 \\
1.00\end{array}$ \\
\hline $\mathrm{Pd}-4$ & 4 & 1350 & 2.00 \\
\hline$P d-5$ & $\begin{array}{r}1 \\
11\end{array}$ & $\begin{array}{l}1490 \\
1375\end{array}$ & $\begin{array}{l}1.50 \\
2.00\end{array}$ \\
\hline$P d-6$ & $\begin{array}{r}5 \\
11 \\
18\end{array}$ & $\begin{array}{l}1420 \\
1360 \\
1320\end{array}$ & $\begin{array}{l}2.00 \\
2.25 \\
1.00\end{array}$ \\
\hline $\mathrm{Pd}-7$ & $\begin{array}{r}2 \\
6 \\
14\end{array}$ & $\begin{array}{l}1430 \\
1365 \\
1290\end{array}$ & $\begin{array}{l}3.00 \\
2.75 \\
1.75\end{array}$ \\
\hline $\mathrm{Pd}-8$ & $\begin{array}{r}1 \\
2 \\
3 \\
5 \\
9 \\
17\end{array}$ & $\begin{array}{l}1480 \\
1490 \\
1490 \\
1465 \\
1425 \\
1330\end{array}$ & $\begin{array}{l}3.50 \\
4.00 \\
3.00 \\
4.00 \\
3.25 \\
2.50\end{array}$ \\
\hline$P d-9$ & $\begin{array}{r}3 \\
4 \\
10\end{array}$ & $\begin{array}{l}1425 \\
1400 \\
1340\end{array}$ & $\begin{array}{l}3.25 \\
1.50 \\
1.25\end{array}$ \\
\hline$P d-10$ & $\begin{array}{r}2 \\
10 \\
13\end{array}$ & $\begin{array}{l}1450 \\
1375 \\
1325\end{array}$ & $\begin{array}{l}3.50 \\
3.50 \\
2.00\end{array}$ \\
\hline$P d-11$ & $\begin{array}{l}4 \\
7 \\
8\end{array}$ & $\begin{array}{l}1390 \\
1370 \\
1345\end{array}$ & $\begin{array}{l}2.50 \\
2.25 \\
4.00\end{array}$ \\
\hline$P d-12$ & $\begin{array}{l}1 \\
2 \\
3 \\
8\end{array}$ & $\begin{array}{l}1395 \\
1390 \\
1395 \\
1345\end{array}$ & $\begin{array}{l}3.25 \\
3.00 \\
5.75 \\
3.50\end{array}$ \\
\hline
\end{tabular}


Table A2. Quantitative Metallography Results for $\mathrm{UO}_{2}+\mathrm{Ag}$ Coated Particles

\begin{tabular}{|c|c|c|c|}
\hline Batch & Particle & $\begin{array}{c}\text { Temperature } \\
\left({ }^{\circ} \mathrm{C}\right)\end{array}$ & $\begin{array}{c}\text { Attack Rate } \\
(\mu \mathrm{m} / \mathrm{h})\end{array}$ \\
\hline $\mathrm{Ag}-1$ & $\begin{array}{r}3 \\
18\end{array}$ & $\begin{array}{l}1455 \\
1290\end{array}$ & $\begin{array}{l}8.00 \\
2.00\end{array}$ \\
\hline $\mathrm{Ag}-2$ & $\begin{array}{r}5 \\
7 \\
8 \\
10\end{array}$ & $\begin{array}{l}1395 \\
1400 \\
1370 \\
1370\end{array}$ & $\begin{array}{l}6.50 \\
3.50 \\
3.00 \\
1.25\end{array}$ \\
\hline $\mathrm{Ag}-3$ & $\begin{array}{r}3 \\
5 \\
15\end{array}$ & $\begin{array}{l}1423 \\
1380 \\
1300\end{array}$ & $\begin{array}{l}3.00 \\
5.50 \\
1.75\end{array}$ \\
\hline $\mathrm{Ag}-4$ & $\begin{array}{r}4 \\
11\end{array}$ & $\begin{array}{l}1390 \\
1300\end{array}$ & $\begin{array}{l}1.00 \\
2.25\end{array}$ \\
\hline$A g-5$ & $\begin{array}{r}4 \\
9 \\
11 \\
12\end{array}$ & $\begin{array}{l}1445 \\
1390 \\
1350 \\
1355\end{array}$ & $\begin{array}{l}8.00 \\
6.00 \\
7.50 \\
8.50\end{array}$ \\
\hline $\mathrm{Ag}-6$ & $\begin{array}{r}4 \\
6 \\
12\end{array}$ & $\begin{array}{l}1445 \\
1410 \\
1350\end{array}$ & $\begin{array}{l}3.50 \\
2.50 \\
1.50\end{array}$ \\
\hline $\mathrm{Ag}-7$ & 12 & 1370 & 12.50 \\
\hline $\mathrm{Ag}-9$ & $\begin{array}{l}7 \\
8\end{array}$ & $\begin{array}{l}1365 \\
1340\end{array}$ & $\begin{array}{l}3.00 \\
1.50\end{array}$ \\
\hline $\mathrm{Ag}-10$ & $\begin{array}{l}1 \\
3\end{array}$ & $\begin{array}{l}1465 \\
1460\end{array}$ & $\begin{array}{l}12.00 \\
14.00\end{array}$ \\
\hline $\mathrm{Ag}-11$ & 9 & 1355 & 7.00 \\
\hline $\mathrm{Ag}-12$ & 6 & 1275 & 9.00 \\
\hline
\end{tabular}


ORNL/TM-7393

Distribution

Category UC-77

\section{INTERNAL DISTRIBUTION}

$\begin{aligned} & \text { 1-2. Central Research Library } \\ & 3 . \text { Document Reference Section } \\ & 4-5 . \text { Laboratory Records Department } \\ & 6 . \text { Laboratory Records, ORNL RC } \\ & \text { 7. ORNL Patent Section } \\ & \text { 8. P. Angelini } \\ & \text { 9. R. L. Beatty } \\ & \text { 10. E. E. Bloom } \\ & \text { 11. T. J. Burns } \\ & \text { 12. R. G. Donne11y } \\ & \text { 13. J. I. Federer } \\ & \text { 14-16. M. R. Hill } \\ & \text { 17. F. J. Homan } \\ & \text { 18. M. J. Kania } \\ & \text { 19-28. R. R. Kasten } \\ & 29 . \text { W. J. Lackey, Jr. } \\ & \text { 30-39. R. J. Lauf }\end{aligned}$

\author{
40. B. C. Les1ie \\ 41. J. S. Lin \\ 42. E. L. Long, Jr. \\ 43. M. F. Osborne \\ 44. A. E. Pasto \\ 45. R. L. Pearson \\ 46. P. L. Rittenhouse \\ 47. D. P. Stinton \\ 48. T. N. Tiegs \\ 49. A. L. Bement, Jr. (Consultant) \\ 50. E. H. Kottcamp, Jr. (Consultant) \\ 51. Alan Lawley (Consultant) \\ 52. T. B. Massalski (Consultant) \\ 53. M. J. Mayfield (Consultant) \\ 54. R. H. Redwine (Consultant) \\ 55. J. T. Stringer (Consultant)
}

EXTERNAL DISTRIBUTION

56-57. DOE, DIVISION OF NUCLEAR POWER DEVELOPMENT, Washington, DC 20545

Director

G. A. Newby

58. SAN-DEVELOPMENT, SAN DIEgO AREA OFEICE, P.O. Box 81325, San Diego, CA 92138

Senior Program Coordinator

59. DOE, SAN FRANCISCO OPERATIONS OFFICE, 1333 Broadway, We11s Fargo Building, Oakland, CA 94612

Manager

60-61. DOE, OAK RIDGE OPERATIONS OFFICE, P.O. Box E, Oak Ridge, TN 37830

Office of Assistant Manager for Energy Research and Development Director, Nuclear Research and Development Division

62-227. DOE, TECHNICAL INFORMATION CENTER, P.O. Box 62, Oak Ridge, TN 37830

For distribution as shown in TID 4500 Distribution Category, UC-77 (Gas Cooled Reactor Technology) 